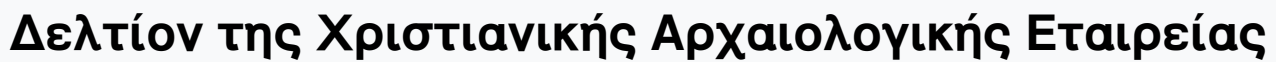

Tó 35 (2014)

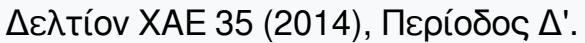

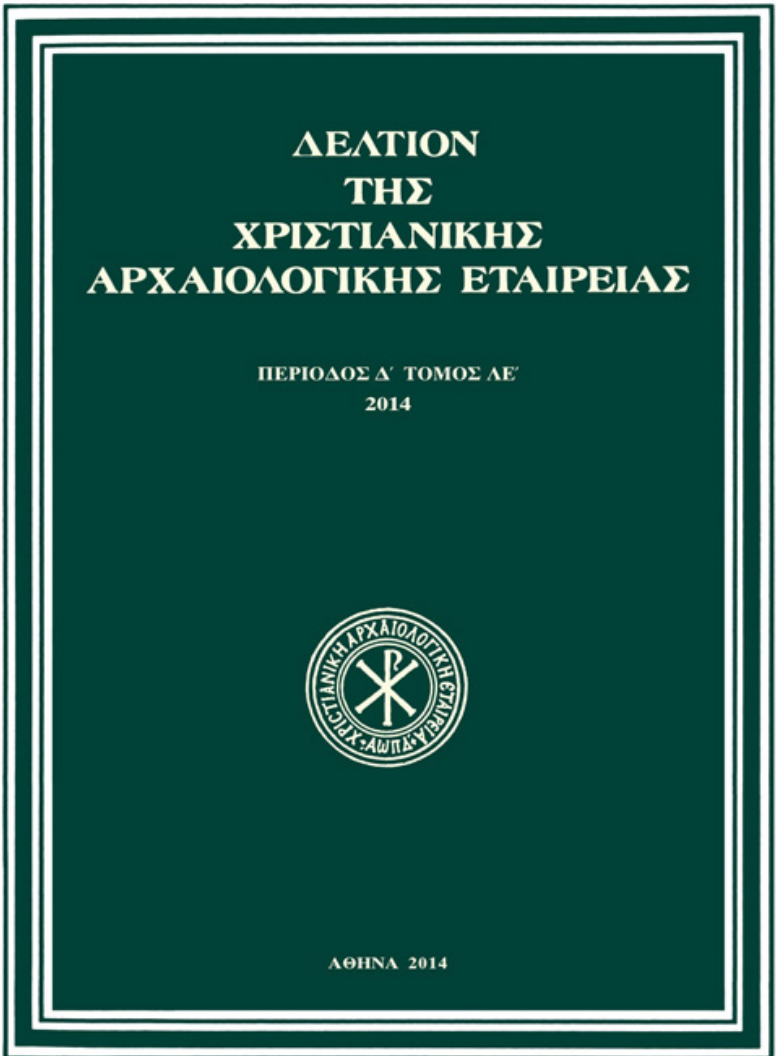

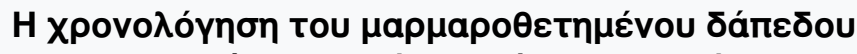

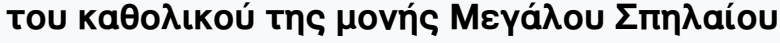

Christina PINATSI

doi: $10.12681 /$ dchae. 1750

Copyright @ 2016, Christina PINATSI

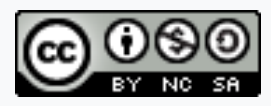

Ađ¿ıı Xpńбnৎ Creative Commons Attribution-NonCommercial-ShareAlike 4.0.

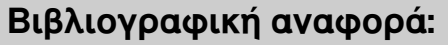

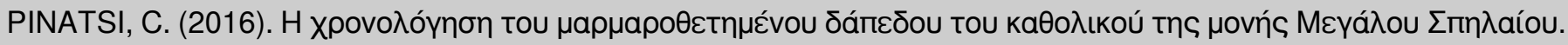

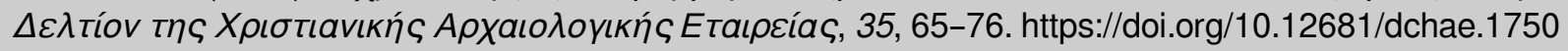




\section{Christina Pinatsi}

\section{THE CHRONOLOGY OF THE OPUS SECTILE PAVEMENT IN THE MEGA SPELAION MONASTERY KATHOLIKON*}

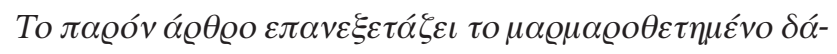

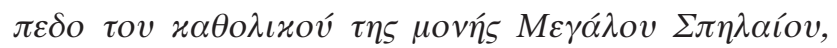

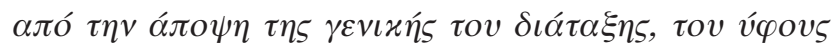

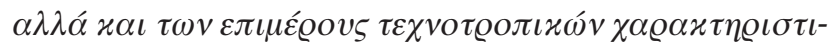

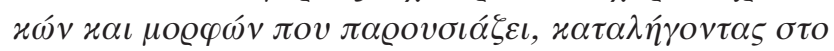

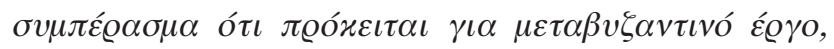

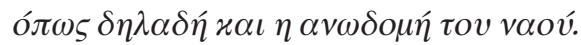

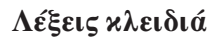

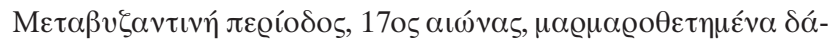

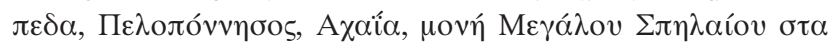

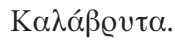

$\mathrm{T}$ he katholikon of the Mega Spelaion monastery, near Kalavryta in Achaia, has gone through multiple destructions and successive re-buildings through the ages. ${ }^{1}$ The present edifice was erected in the year $1641 .^{2}$ Quite recently, it has been claimed that the pavement adorning the church belongs to a previous (namely, Palaeologan) construction phase. ${ }^{3}$

\footnotetext{
* I would like to thank the members of the editorial committee of the Christian Archaeological Society for their uninterrupted efforts for the annual publication of the Deltion and for favourable reception of the present paper. In particular, I would like to express my deep gratitude to the paper's referees for their invaluable contribution and observations, and to the text editors for their meticulous work and improvements to the English text. Finally, I would like to thank Professors Bouras and Mamaloukos for proof-reading the article before submission.

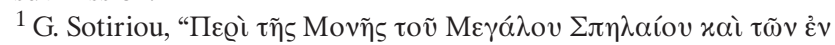

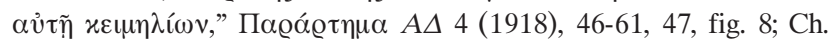
Chotzakoglou, Untersuchungen zur Geschichte, Architektur und Wandmalerei der Klosterkirche Mega-Spelaion auf der Peloponnes, Philosophisches Fakultät, Institut für Byzantinistik und Neograzistik Universität Wien, Austria 1997 (doctoral thesis).

${ }^{2}$ Sotiriou, op.cit. (n. 1), 47; Chotzakoglou, op.cit. (n. 1), 124.

${ }^{3}$ Ibid., 139 , followed by a more extensive analysis by the same author:
}

The present paper re-examines the opus sectile pavement of the katholikon of Mega Spelaion monastery, in terms of its general arrangement, its style and the partial features and forms that it presents, to reach the conclusion of a Post-Byzantine dating, thus corresponding to the chronology of the full reconstruction of the church edifice.

\section{Keywords}

Post-Byzantine period, 17th century, opus sectile pavements, Peloponnese, Achaia, Mega Spelaion monastery near Kalavryta.

Preservation of pavements after the destruction of the superstructure is not uncommon, ${ }^{4}$ so this hypothesis would be technically feasible. However, in order to establish this hypothesis, the form of the pavement should convince us of a Byzantine dating, which is not the case.

The pavement is characterised by a perfectly symmetrical layout of rectangular panels defined by continuous

Ch. Chotzakoglou, "Ein Kaiserliches spätbyzantinisches opus sectilePaviment aus der Klosterkirche von Mega Spelaion, Peloponnes: Technik, Thematik und Symbolik," Wiener Byzantinistik und Neogräzistik, XXIV, Vienna 2004, 99-131.

${ }^{4}$ As in the katholika of Varnacova monastery, Phocis (A. Orlandos,

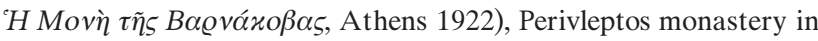
Politika, Euboea [St. Mamaloukos - Ch. Pinatsi, " $\Sigma v \mu \pi \lambda \eta \varrho \omega \mu \alpha \tau \iota x \alpha ́$

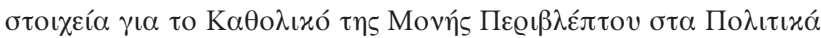
Evßoías", AEvM $\Lambda Z^{\prime}$ (2007), 71-82], Lechova monastery, Korinthia

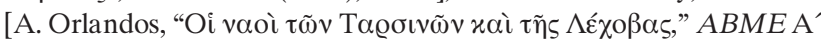

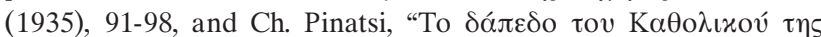

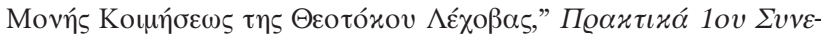

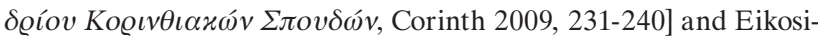

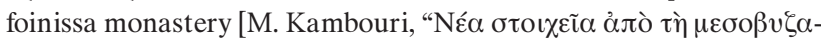

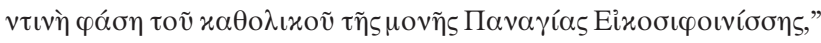

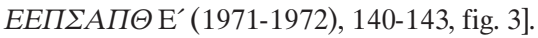




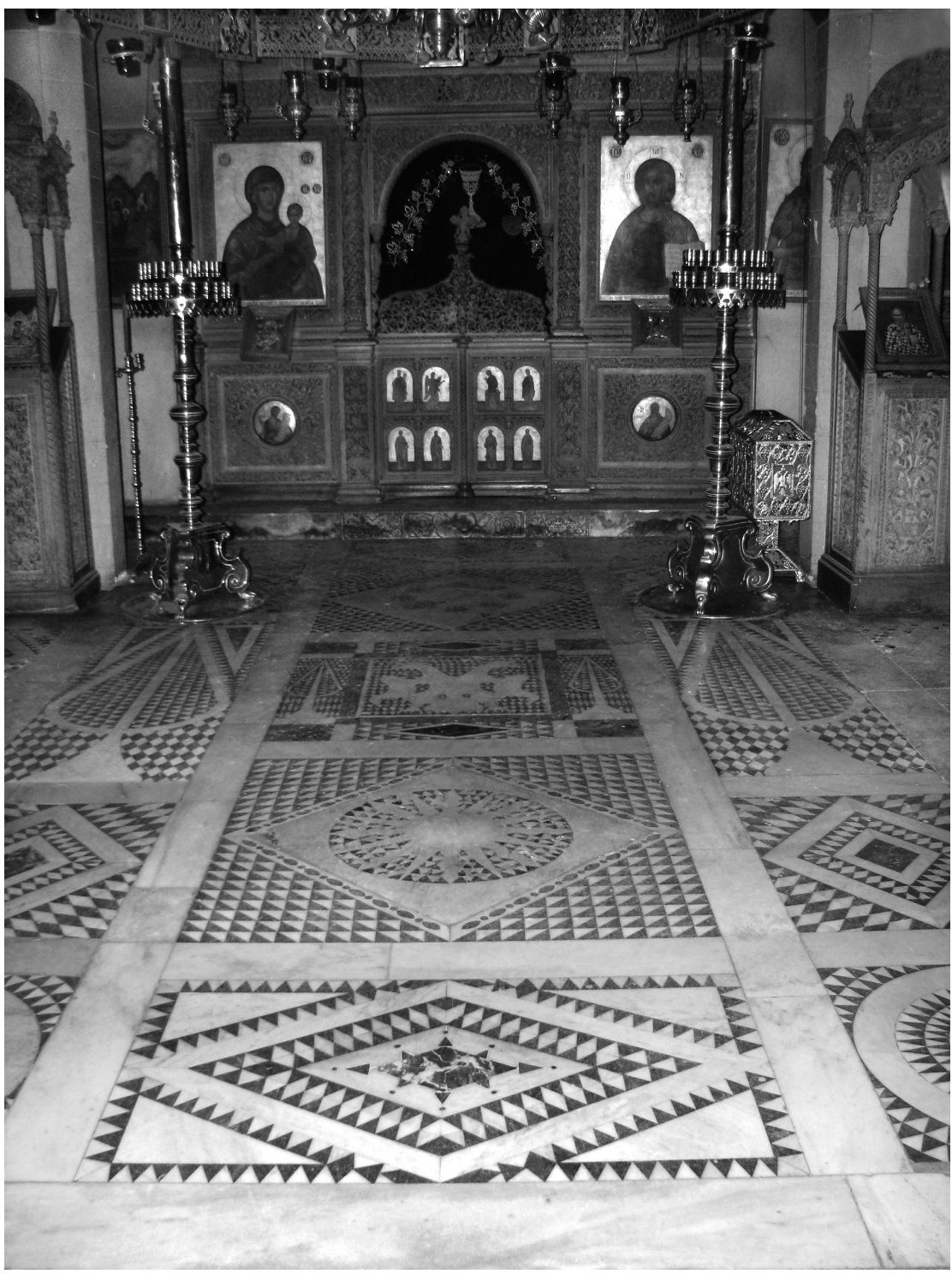

Fig. 1. Mega Spelaion, katholikon. General view of the central nave.

bands of white marble whose width remains unaltered throughout (Fig. 1). The ground is filled by opus sectile everywhere executed in black and white and forming the same pattern (rows of triangles), ${ }^{5}$ acting as a background for decorative elements of white marble, such as lozenges,

\footnotetext{
${ }^{5}$ Rows of lozenges have been inserted in modern repairs; however, the extant authentic parts reveal that initially, these were also formed by two triangular crustae. The rows of triangles are the simplest and therefore commonest pattern in Ottoman period bands of
}

circles, X-forming bands, double-headed eagles (Fig. 5), etc. Some sporadic coloured stones are isolated and do not appear in opus sectile motifs. The impressive central panels (Fig. 2) include two large symmetrical cypresses flanking the central feature, a double-headed eagle flanked by 


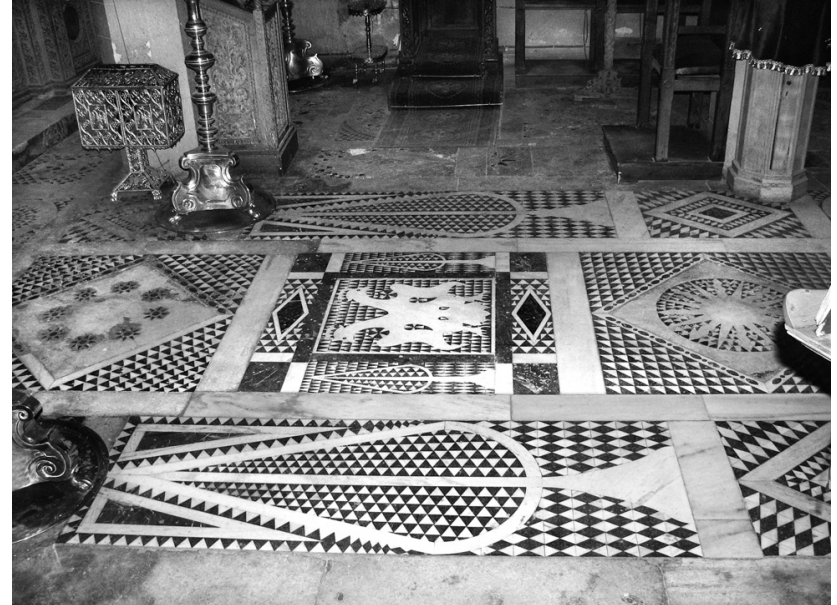

Fig. 2. Mega Spelaion, katholikon. View of the central part of the pavement from the north. It is noted that this area has been restored, but the original design has been reproduced accurate$l y$, as the form of the pavement is identical in the picture published by Soteriou in 1918 (see n. 1), where the original parts were still extant.

two smaller cypresses. In many panels, the central decorative slabs have incrustations (Figs 3, 9, 11) depicting stars and the sun or astragal (beed-and-reel) frames. Finally, the four peripheral disks of each "quincunx" in the northeast and south-east panel of the naos are formed by flower-shaped relief rosettes (Figs 6-7). ${ }^{6}$

All the above-mentioned features lend the pavement a character unrelated to Byzantine works of this kind. In particular, the absolute symmetry and rigidity of the composition - extending even to the symmetrical arrangement of identical motifs - is not related to medieval art, which con-

\footnotetext{
${ }^{6}$ For a more detailed description and drawing see Chotzakoglou, op.cit. (n. 1), 102-106, 131.

${ }^{7}$ As regards accuracy and symmetry and the filling of panels with opus sectile and the bitonal taste of patterns, cf. the 17th century pavement from a manor house of Cairo, reconstituted in the Islamic

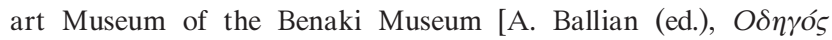

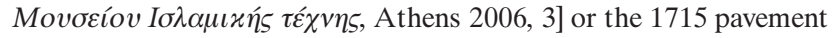
in the central nave of the katholikon of Hagia Aikaterini's monastery

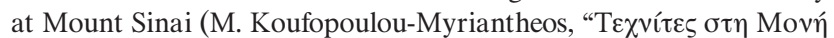

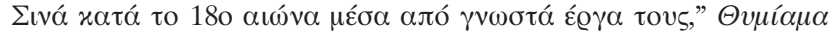

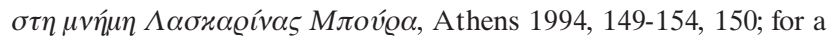

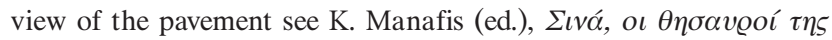
Movńs, Athens 1990, 55, fig. 24). The black-and-white inupression and the form of the crustae also remind the opus sectile panels in Topkapi palace, as in the portico of Ahmed III's library.

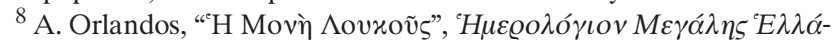
$\delta o \varsigma 3(1924), 419-433$. In a more recent article, it has been suggested
}

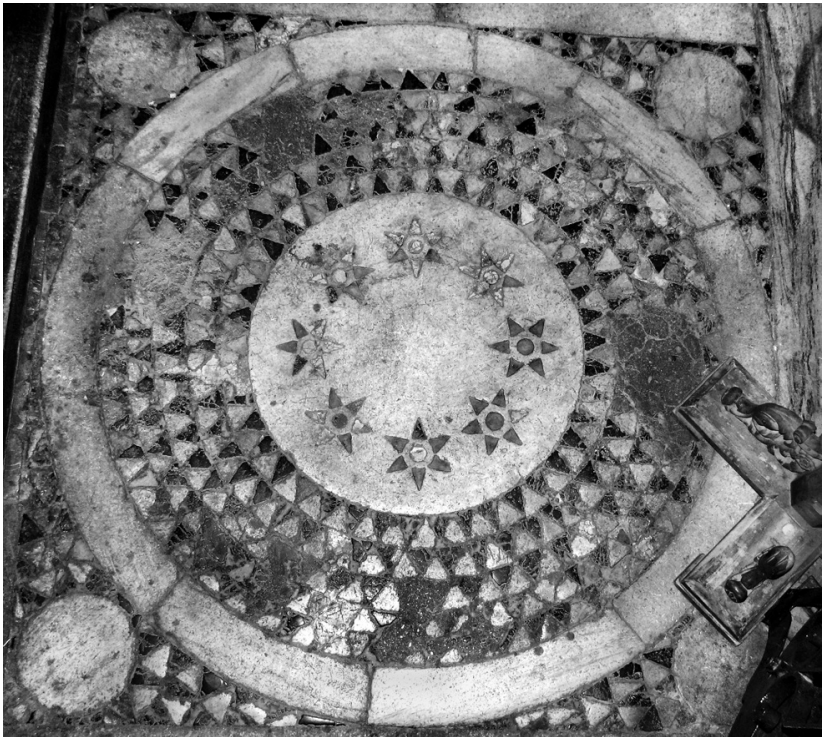

Fig. 3. Mega Spelaion, katholikon. A non-interlacing, simple omphalion, with the same motif repeated in the spandrels and the central area, and incrustation of stars on the central disk.

sciously sought variety, but rather to an era resonant of the Renaissance, which has brought back the role of discipline to a uniform architectural design. The overall impression and style recall Post-Byzantine examples ${ }^{7}$ such as the Loukou monastery, ${ }^{8}$ where of course the existence of readily-available crustae from the nearby villa of Herod Atticus defined the size and patterns of opus sectile.

The lack of variety at Mega Spelaion is also underscored by the recurrence of the same opus sectile pattern (rows of black and white triangles) ${ }^{9}$ in the background of all the panels. This repetition does not appear in any

that the Loukou pavement also belongs to an earlier Byzantine construction phase [G. Poulimenos, "Tò $x \alpha \theta 0 \lambda \iota x o ̀ ~ \tau \tilde{\eta} \varsigma$ Movñ $\Lambda$ Nov-

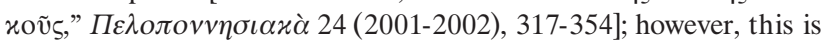
probably based on the erroneous interpretation of the opus sectile as Byzantine, which fails to take into account the fact that the opus sectile at Loukou has merely reused crustae and patterns taken from the nearby Roman villa of Herod Atticus, and is not a Byzantine work.

${ }^{9}$ In order to avoid any misunderstandings, I should note that omphalia with circular rows of triangles surrounding a central disc, as in Fig. 8, as well as rectilinear rows of triangles exist in Byzantine works. They are, however, very different in their execution, especially the circular ones, which usually aim to create a visual effect by diminishing sizes or alternating colours. Examples in the katholika of Perivleptos at Politika (supra n. 5), Varnakova (supra n. 5), Lechova (supra n. 5), Iviron monastery [D. Liakos, "The Byzantine opus sectile floor in the Katholikon of Iveron Monastery on Mount Athos," Zograf 32 (2008), 37-44]. 


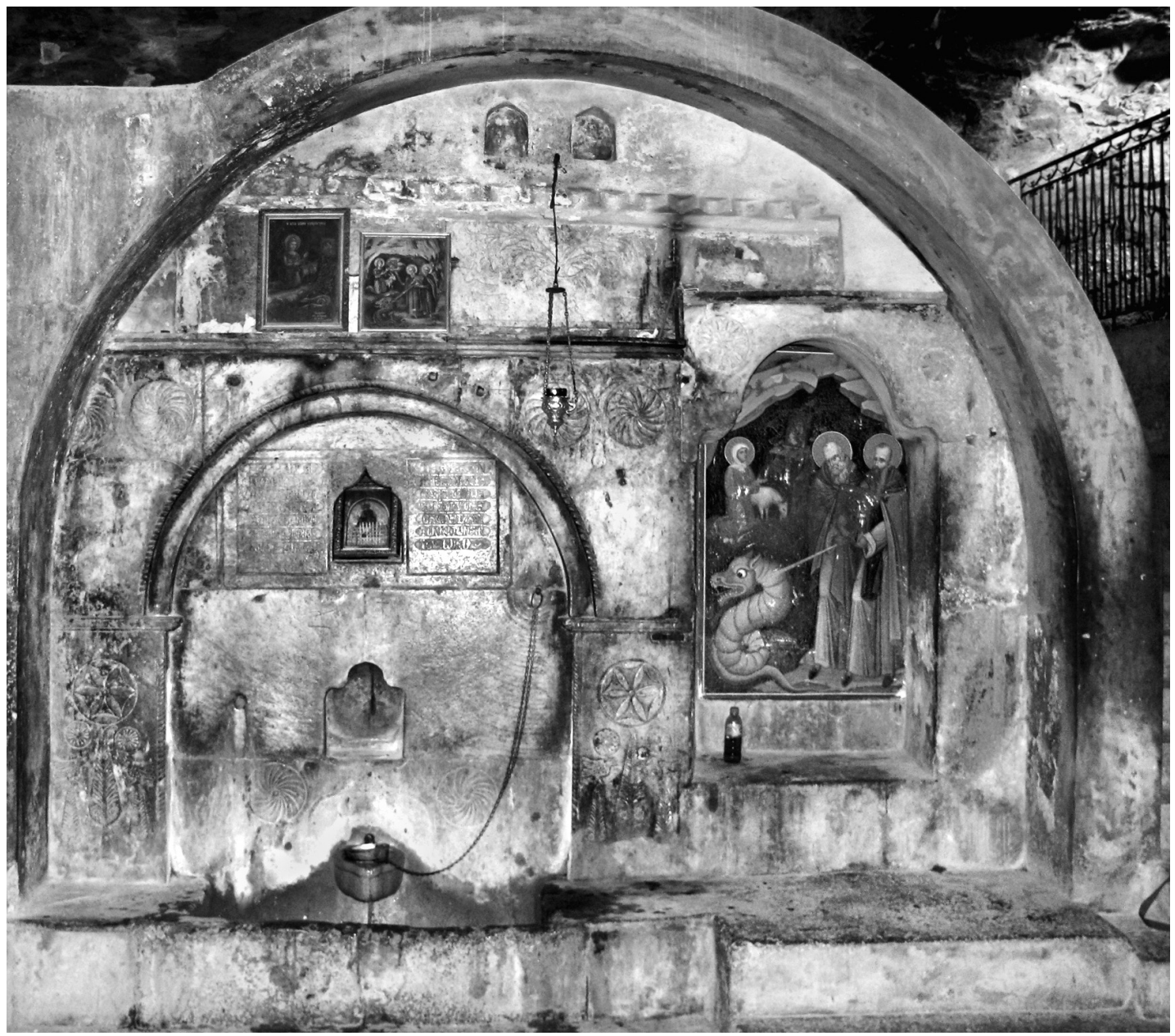

Fig. 4. Mega Spelaion, the fountain. Cypresses, not well discernible, adorn the bases of the pilasters.

Byzantine floor, where differentiation of patterns is meticulously pursued, even through limited variations in size or colour combinations. Furthermore, the very filling of the "ground" with opus sectile is a feature that does not correspond to Middle or Late Byzantine art, and this is in fact the most substantial difference between Middle/Late Byzantine pavements and contemporary Cosmati work, as well as Early Christian opus sectile. ${ }^{10}$

As regards the main decorative themes, in Mega Spelaion there is no intricate interlacing of circles or marble strips,

\footnotetext{
${ }^{10}$ A. Guidobaldi, "Tradizione locale e influenze byzantine nei pavimenti cosmateschi," Bolletino d'Arte 26 (1984), 57-72.

11 The only Byzantine omphalion known to me that bears an arrangement similar to the easternmost panels of the naos of Mega Spelaion (Fig. 5 below; details in Figs 6-7), combining a lozenge with
}

which is the hallmark of Byzantine omphalia. Although there are arrangements combining more than one circle or rectilinear shape, the more complicated connection so dear to the Byzantines that involved the linking and interlacing of marble bands is avoided ${ }^{11}$ (Fig. 3). In addition, some easilycreated patterns common to the majority of Byzantine decorated pavements are absent (such as variants of an oblique chessboard, where either the dark or light squares are formed by more complex combinations of triangles and squares parallel to the main axis of the decorative band).

five circles without interlacing, is found in Andromonastiro in

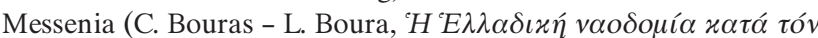
$12 o$ di $\omega \alpha$, Athens 2002, fig. 482); nevertheless, it is totally different in style, its chromatic preferences, and the scale and variety of its motifs. 
In contrast, the incorporation in the pavement of features typical or even peculiar to the art of the Ottoman period attests to its chronology.

- The presence of cypresses in Early Christian and Byzantine sculpture does not suffice as an argument for the Late Byzantine dating of the pavement, ${ }^{12}$ since the cypress, especially in the particular stylized form ${ }^{13}$ it displays here (Fig. 2), appears more generally in the art of the Ottoman period. ${ }^{14}$ There is even an example on the fountain of the monastery itself (Fig. 4).

- Even though double-headed eagles made their appearance from the Late Byzantine period ${ }^{15}$ (though from examples of pavements cited, ${ }^{16}$ at the Vlacherna of Arta we do not actually have the eagle's head, so it could well be one-headed, ${ }^{17}$ while at the Metropolis of Mystra the slab bearing the double-headed eagle was set later, during the period of Ottoman rule) ${ }^{18}$ they appear mostly in the form of relief slabs in pavements dated to the Ottoman period (the Loukou monastery, ${ }^{19}$ incorporation of the eagle slab at Hagios Demetrios of Mystra, ${ }^{20}$ the Prophet Elijah of Siatista, ${ }^{21}$ the Three Hierarchs, ${ }^{22}$ and the Hypapante church on Hydra, ${ }^{23}$ Panaghia ta Gournia on Sifnos, ${ }^{24}$ to name only a few), and have in fact been linked to the desire for national liberation. ${ }^{25}$ The rich delineation of the

\footnotetext{
${ }^{12}$ Chotzakoglou, op.cit. (n. 1), 112; the slab from Politica mentioned has no connection to the period of the respective opus sectile pavement of the katholikon, as it dates to the Early Christian era [A. Or-

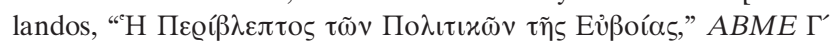
(1937), 180, fig. 6].

${ }^{13}$ With rigid almond-shape form and a base that widens towards the bottom.

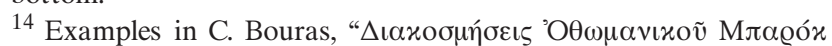

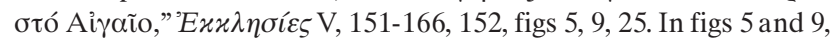
the form of the cypress base characteristic of Mega Spelaion is also observed. More examples in A. Goulaki-Voutira, " $\Delta \varepsilon\{1 \gamma \mu \alpha \tau \alpha \mu \alpha \varrho \mu \alpha-$

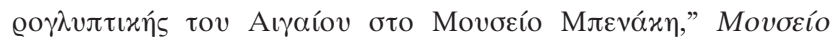
Mлєváxๆ 2 (2002), 111-123, figs 1, 2, 3, 5, 7, 10, 13. The examples cited belong mostly to the 18th century; however, Prof. Bouras notes that cypresses are among the Ottoman features of the previous two centuries that continued in use. A similar form is found on the Cha-

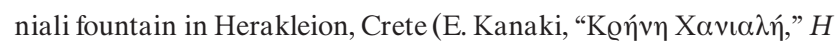

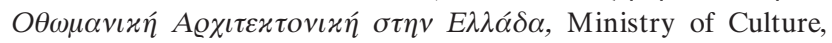
$\triangle B M A, 2008,409)$ and on the pavement slab at Panaghia ta Gournia

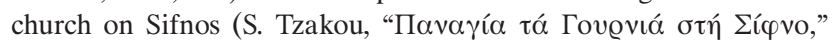
${ }^{~} E \varkappa \varkappa \lambda \eta \sigma i \varepsilon \varsigma I V$, fig. 8). On this topic, see also A. Petronotis, "To

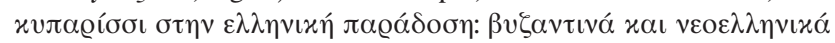

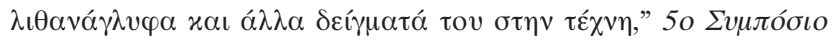

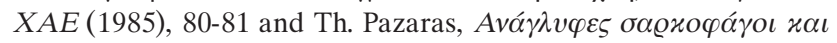

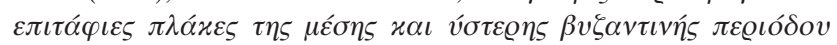
$\sigma \tau \eta v E \lambda \lambda \alpha ́ \delta \alpha$, Athens 1988, 104.

${ }^{15} \mathrm{P}$. Androudis, "Dalle avec aigle bicéphale, en provenance de l'enceinte
}

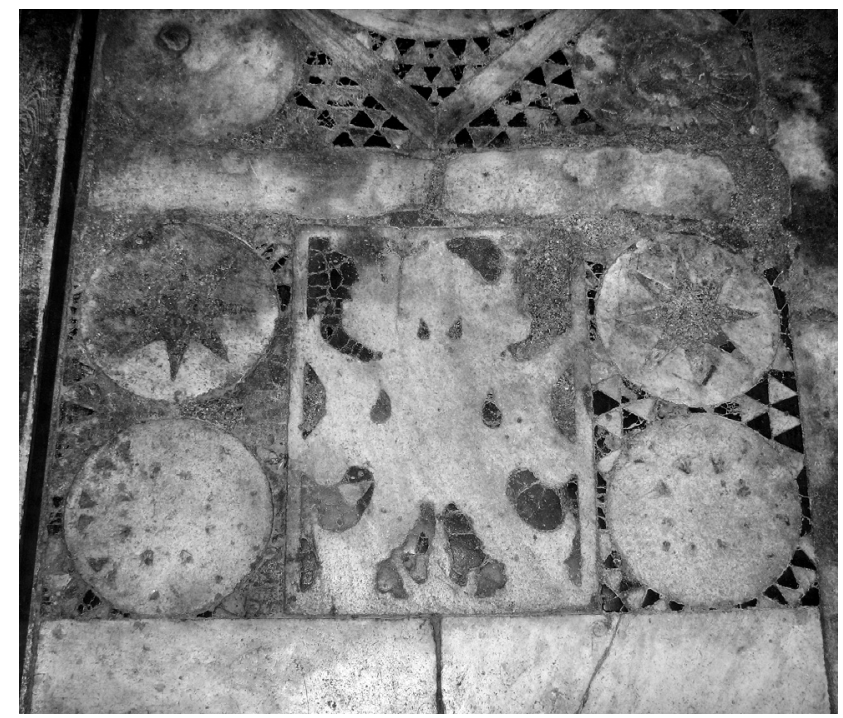

Fig. 5. Mega Spelaion, katholikon. A double-headed eagle motif on the pavement.

eagles' plumage at Mega Spelaion (Fig. 5), which achieves a mood of baroque decorative exaggeration, recalls PostByzantine models rather than the stylized Byzantine representations of the same figure. ${ }^{26}$

byzantine de Trébizonde," $\triangle X A E \Lambda \Delta^{\prime}$ (2013), 74.

${ }^{16}$ Chotzakoglou, op.cit. (n. 1), 112-113.

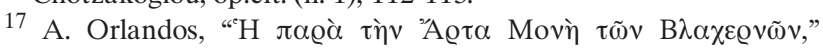
ABMEB' (1936), 3-50, fig. 25.

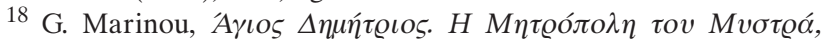
Athens 2002, 77, including relevant bibliography.

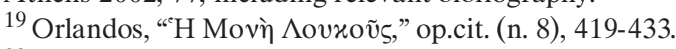

${ }^{20}$ Marinou, op.cit. (n. 18), 77.

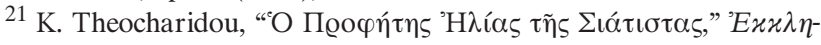
бí $\varsigma$ I, 55-66, figs 6, 9, 10, 11.

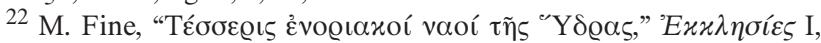
271-286, fig. 13.

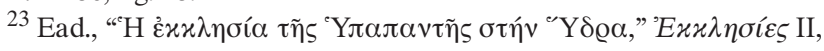
225-236, figs 11, 12.

${ }^{24}$ Tzakou, op.cit. (n. 14), 215, fig. 8.

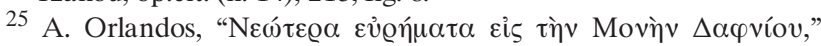
$A B M E \mathrm{H}^{\prime}$ (1955-1956), 95; on the national and religious significance as well as the iconography of the double-headed eagle, also see

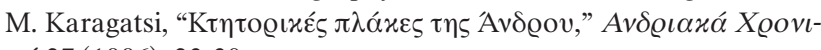
xó 27 (1996), 23-30.

${ }^{26}$ Byzantine stylized eagle representations (not double-headed) are met for instance on a floor slab at the Holy Trinity of Kriezotis

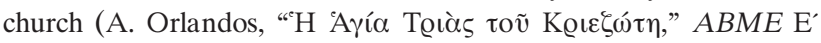
(1939-1940), 3-16), and on a slab of the marble screen at Hagia

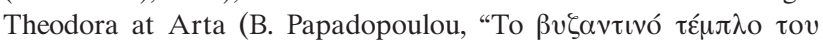

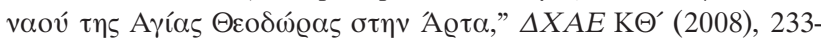
46). See also n. 19 above. 

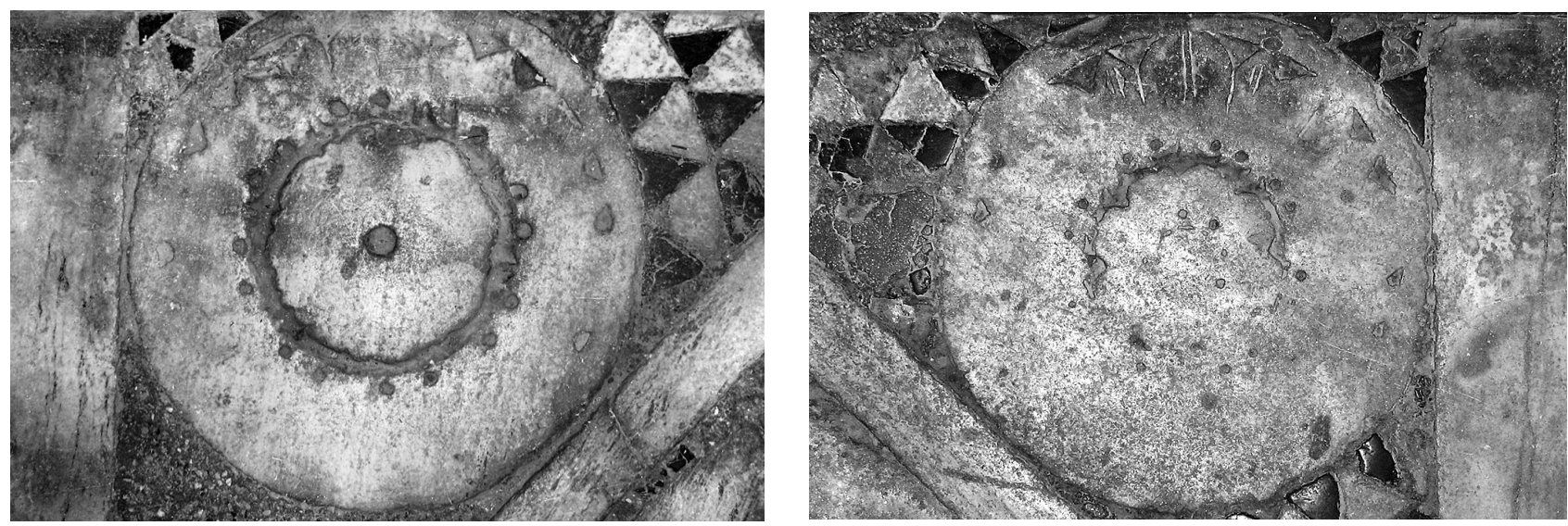

Figs 6-7. Mega Spelaion, katholikon. Two worn-out relief rosettes, partially covered by the Post-Byzantine sculptured parts in second use as stylobate to the later iconostasis.

- The four relief rosettes (Figs 6-7) adorning the corners of the easternmost panels of the naos, ${ }^{27}$ which were placed from the outset and have a clear ornamental purpose, are characteristic works of stone carving during the Ottoman period, analogous to the typical Turkish rose. ${ }^{28}$ The incorporation of reliefs other than champlevé - incrustation slabs is very unusual in Byzantine pavements, whereas it became fairly common in Post-Byzantine times. ${ }^{29}$ The rosette with two concentric rings, the inner one forming the core of the flower and the outer one depicting its petals, is a feature found in Byzantine sculpture through the last centuries of the first millennium, ${ }^{30}$ but the pieces in Mega Spelaion do not seem to be spolia ${ }^{31}$ since this element enjoyed a revival in the Ottoman decorative arts during the 16th and 17th centuries (as did comparable capitals with reed leaves), ${ }^{32}$ expressing the period's tendency towards rich floral ornamentation, ${ }^{33}$ and adorning as a leitmotiv Ottoman mosques, mihrabs, and fountains from the time of Sinan..$^{34}$ In Greece they often appear in stonecarved works of the Ottoman period (fountains, baths,

${ }^{27}$ Chotzakoglou, op.cit. (n. 1), 105.

${ }^{28}$ For reference to the motif and its diffusion in Post-Byzantine

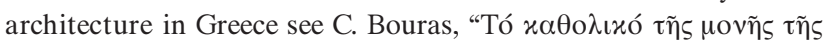

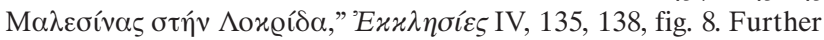

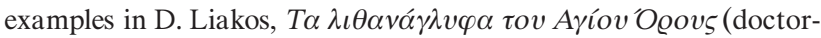
al thesis), Aristotle University of Thessaloniki 2000, figs 158, 159, 197. For additional examples see also infra, nn. 35-36.

${ }^{29}$ Floral relief slabs are prominently incorporated in the PostByzantine pavement at the entrance to the katholikon of Loukou monastery (see supra, n. 9). For the incorporation of Post-Byzantine relief slabs within the pavements of the katholika of Mount Athos, see Liakos, op.cit. (n. 28), 42-43, figs 129-132, where some additional instances of the double-headed eagle motif are presented.

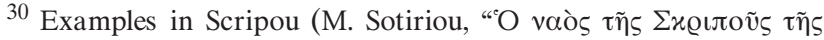

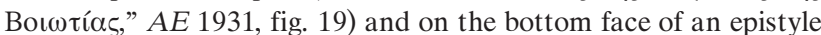
from Corinth (R. L. Scranton, Medieval Architecture, Corinth XVI, Princeton 1957, pl. 33, no. 157), which was recently dated to the 8th9th century [D. Athanasoulis - G. Velenis, " $\Sigma v \mu \pi \alpha \varrho o \mu \alpha \varrho \tau o v ́ v \tau \alpha$

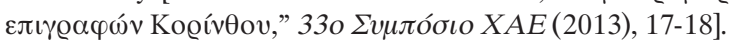

${ }^{31}$ Even if the rosettes were Byzantine works, this would not indicate a Late Byzantine dating rather than a Post-Byzantine one for the pavement, since either way the motif should be attributed to much

earlier times and considered as spolia.

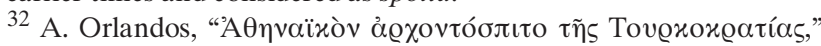
ABME E' (1939-1940), 201. The capitals in question imitate much earlier examples (cf. A. Orlandos, ' $H \xi v \lambda o ́ \sigma \tau \varepsilon \gamma o \varsigma \pi \alpha \lambda \alpha \iota 0 \chi \varrho \iota \sigma \tau \iota \alpha-$

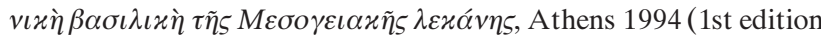
1952-1956), 294-295.

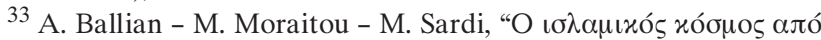

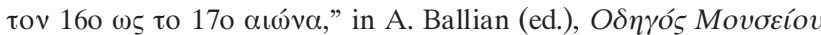

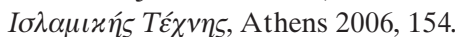

${ }^{34}$ See for instance the Sokullu mosque (Cadirga) and Suleyman's Mausoleum in R. Günay, Sinan, the Architect and his Works, Istanbul 1998, 95 and 153, respectively. Examples on stone-carved fountains and mihrabs in G. Goodwin, A History of Ottoman Architecture, Baltimore 1971, figs 228, 387, 390. Rosettes of simpler form appear in earlier Islamic art, but the richly ornamental and composite form of a more naturalistic flower is characteristic of Ottoman art from the 16th century onwards [Ballian - Moraitou - Sardi, op.cit. (n. 33), 154]. Other examples, almost identical to the Mega Spelaion rosettes, are found in Ahmed III's fountain near Topkapi palace in Constantinople, and at the wall fountain just inside of the second courtyard main gate (Bab-üs Selam or Orta Kapi) at Topkapi palace (Fig. 8). 
gates, etc.). ${ }^{35}$ It has been suggested ${ }^{36}$ that the flowers depicted are tulips. However, tulips, which were actually a flower cherished by the Ottoman court and perhaps the most celebrated floral figure in Ottoman art during the 16th and 17th centuries, ${ }^{37}$ are preferentially depicted frontally due to their characteristic shape, and do not have as many petals; thus I believe the rosettes must represent other multi-petal flowers.

- Stars, suns, and the like also appeared in Late Byzantine pavements, but with a totally different style. ${ }^{38} \mathrm{Be}-$ sides, they are the rule in the decorative trends of PostByzantine church pavements (church of the Nativity of the Virgin at Gortsouli, Mantineia, ${ }^{39}$ Pr. Elijah in Siatista, ${ }^{40}$ and most of the Post-Byzantine Athonite katholika). ${ }^{41}$

The presence of the aforementioned figures (doubleheaded eagles, cypresses, celestial bodies) is also common in stone reliefs on the façades of Post-Byzantine churches

$35 \mathrm{Cf}$. the bath at Koraka square, Herakleion, Crete (E. Kanetaki,

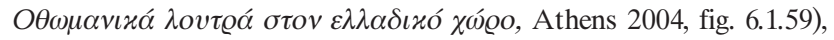

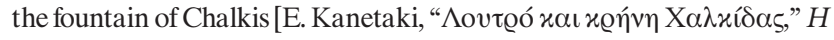

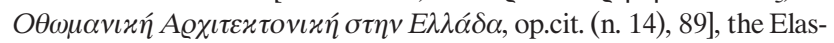

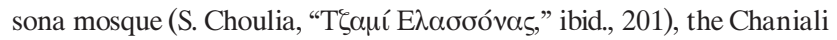

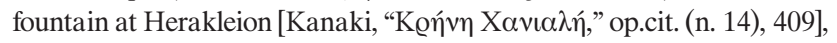

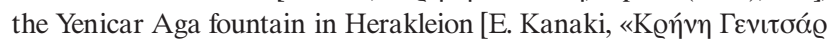

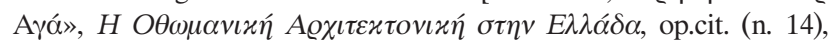

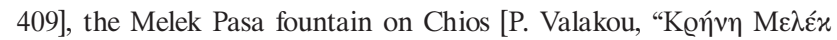

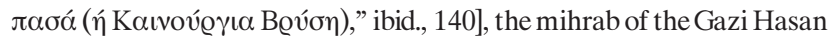

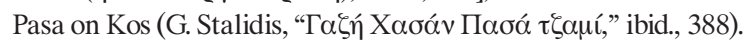

${ }^{36}$ Chotzakoglou, op.cit. (n. 1), 105.

${ }^{37}$ In the Ottoman court the love for tulips was due not only to the attractiveness of the plant, but also to a symbolism attributed to it because the shape recalled the script for the word "Allah." The extensive use of the flower in the decorative arts during the 16th and 17th centuries resulted in the designation of a period in the 18th century (1718-1730) as the "tulip era." In parallel, the interest of European botanists in the tulip, imported to the West from the Ottoman court, led to the so-called tulipomania [F. Uluengin - B. Uluengin - M. B. Uluengin, Classic Construction Details of Ottoman Monumental Architecture, Istanbul 2001, 213-220, and Ballian - Moraitou - Sardi, op.cit. (n. 33), 154].

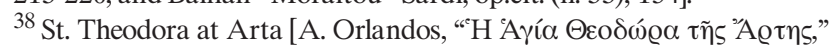
ABME B' (1936), 88-104, figs 3, 12], Perivleptos church at Mystra (G. Millet, Monuments byzantins de Mistra, Paris 1910, pl. 44.17, 44.19). The fragmentarily preserved pavement of the Perivleptos of Mystra [A. Louvi, L'architecture et la sculpture de la Périvleptos de Mistra (doctoral thesis), Université de Paris I - Panthéon - Sorbonne 1980 pl. 6], constitutes a particular case, where crustae in second use, apparently retrieved from a Roman or Early Christian marble revetment, have been oddly re-arranged, and is therefore not suitable for comparisons. Other Middle and Late Byzantine pavements cited by Chotzakoglou as depicting suns [Chotzakoglou, op.cit. (n. 1), 112 n. 51], such as the Imrali (Kalolimnos) island pavement [F. W. Hasluck, "Bithynica," BSA XIII (1906-1907), 284-308] and the omphalion of Hagia Sophia in Nicaea [Ch. Pinatsi, "New Observations on the Pavement of the Church of Haghia Sophia in Nicaea," BZ 99 (2006), 119-126, with additional

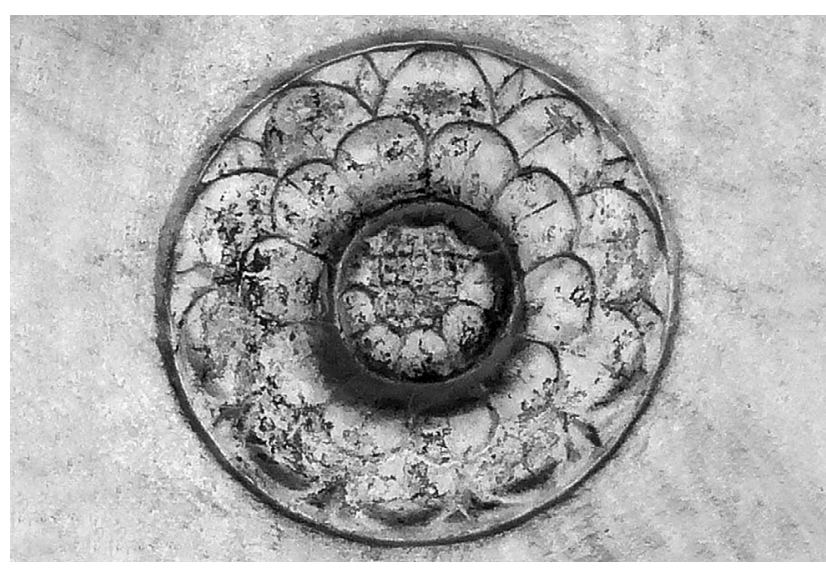

Fig. 8. Topkapi palace. Detail of rosette from the fountain inside of the second courtyard main gate (Bab-üs Selam or Orta Kapi).

bibliography], merely include roundels surrounded by opus sectile bands with radically-disposed triangles, a common theme with many variations. The suns of the Mega Spelaion pavement are in a totally different, more "realistic" style, with wavy rays (Fig. 9) carved in marble [cf. the more recent (early 19th century) pavement of Holy Golgotha in the Resurrection church, seen in Al. Kariotoglou, $M \eta^{-}$

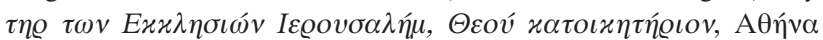
1998,145 , or the 1833 cobbled courtyard of the church of the Virgin

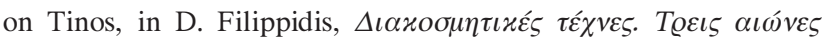

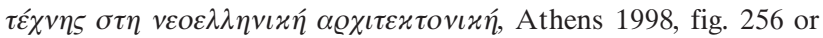
specifically inlaid incrustations to depict rays (Fig. 6)].

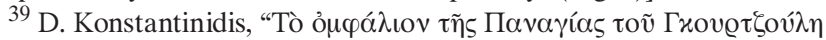

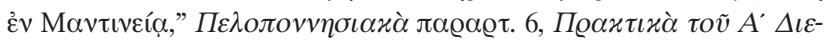

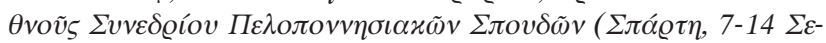
$\pi \tau \varepsilon \mu \beta \varrho i ́ o v ~ 1975)$, Athens 1976-1978, vol. B', 55-65, and Ch. Pinatsi,

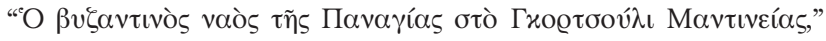

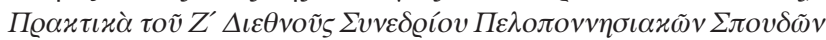

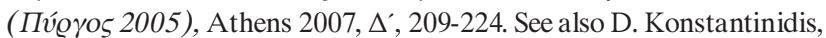

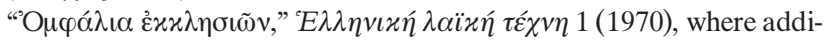
tional examples are mentioned.

${ }^{40}$ Theocharidou, op.cit. (n. 21), 55-66, figs 6, 9, 10, 11.

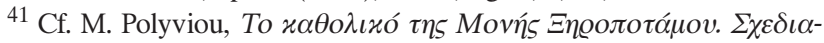

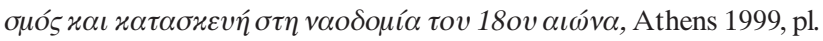

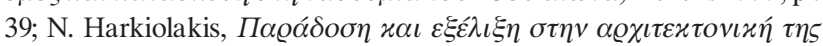

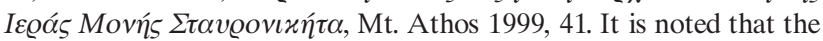
date of the Stavroniketa pavement has also been questioned [Chotzakoglou, op.cit. (n. 1), 116 n. 75]; nonetheless, the central slabs with inlaid lead present a design of utterly Ottoman taste, with a morphology corresponding to the aesthetics of typical Islamic traceries or even timber artwork [cf. Liakos, "The Byzantine opus sectile floor," op.cit. (n. 9), 39, fig. 2]. In fact it has been constructed by rearranging a previous work; thus, the introduction of Ottoman ornament which gradually took place after 1453 constitutes a terminus post quem for the final laying of the pavement. The central motif in particular, with its star and radically-disposed pointed hexagonal gaps, derives from the most emblematic motif of Ottoman geometric decoration (examples at the Minbar of Selimiye mosque in Adrianople (G. Goodwin, A 


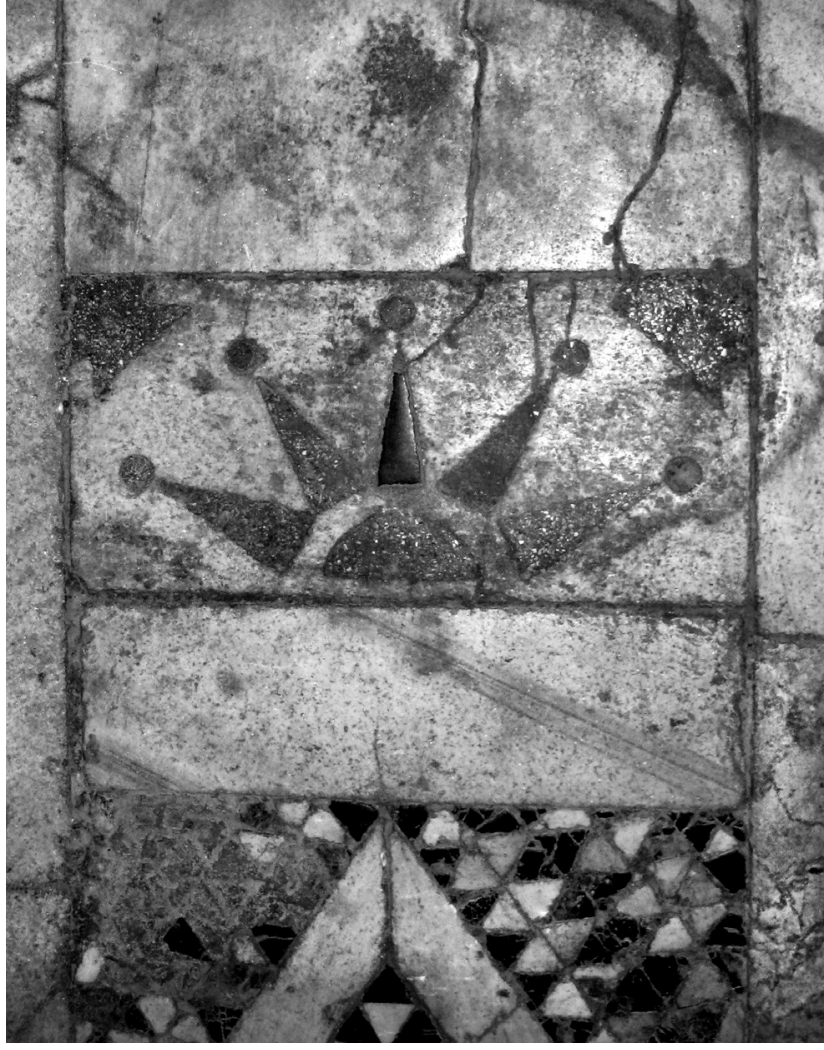

Fig. 9. Mega Spelaion, katholikon. A sun incrustation on a marble slab.

in Greece. Two slabs on the façade of the later church of Hagios Georgios in Solos near Kalavryta ${ }^{42}$ may be mentioned as indicative, because of their close geographic proximity: one bears a double-headed eagle and the other the sun, surrounded by the names of the months and symmetrically flanked by two cypresses.

History of Ottoman Architecture, Baltimore 1971, fig. 253) and the Mihrimah Sultan mosque in Chryssoupolis [Günay, Sinan, op.cit. (n. 34), 239] as well as on many doors (Ibid., 229).

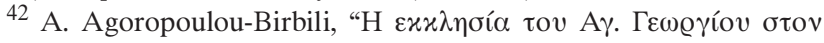

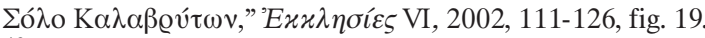

${ }^{43}$ Chotzakoglou, op.cit. (n. 1), 103-104, 113.

44 As in the Pantokrator monastery, Constantinople [A. H. S. Megaw, "Notes on Recent Work of the Byzantine Institute in Istanbul," DOP 17 (1963), 335-364; P. Underwood, "Notes on the Work of the Byzantine Institute in Istanbul, 1954,” DOP 9-10 (1954), 299300; P. Schweinfurth, "Der Mosaikfußboden der Komnenischen Pantokratorkirche," AA (1954), 356-360], Stoudios monastery, Constantinople (Megaw, op.cit., 339) and some crustae found in excavations near Raidestos [Известия Русскаго Археологическаго Института въ Константинополь XVI (1912), 380, pl. IV]. For a commentary see also Ch. Pinatsi, "Regional Trends and International Exchange in the

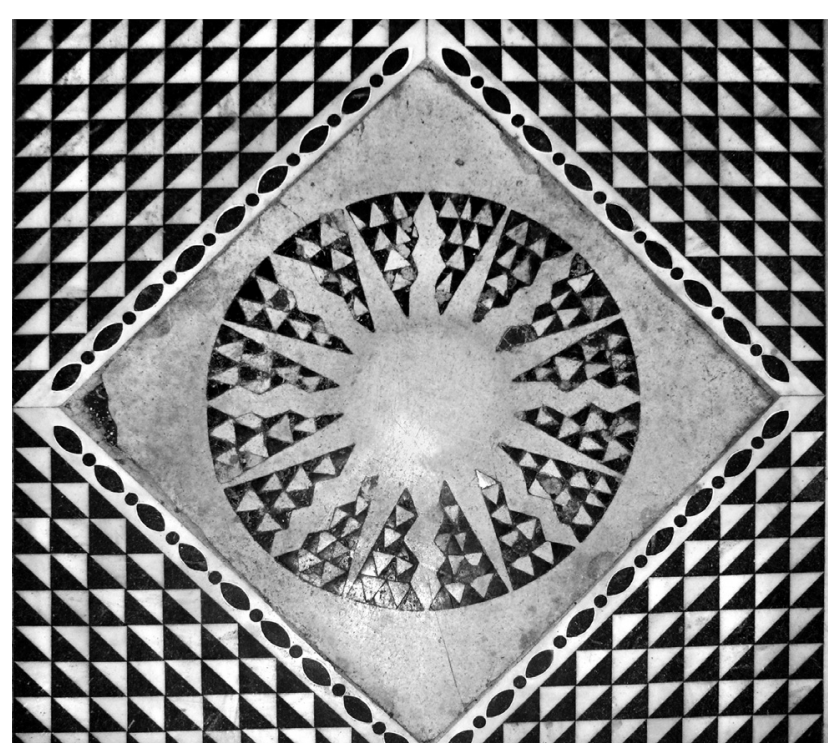

Fig. 10. Mega Spelaion, katholikon. A sun motif on a marble slab.

With regard to iconography, figurative representations lost from the Mega Spelaion pavement (a heart with two arrows, a soldier with a lance, a siren), known from texts ${ }^{43}$ are not suitable for technical comparisons to Middle Byzantine works, since we have not seen their execution or technique. The specific figures mentioned, however, may lead to some thoughts and observations. Either way, the technical and stylistic differences between the Mega Spelaion pavement and Middle Byzantine ones that contain figurative elements (persons or mythical creatures $)^{44}$ or heart-shaped crustae, ${ }^{45}$ renders any relevance of these works to the Mega Spelaion implausible. There is no reason to assume, therefore, that the lost figures had

Art of Marble Pavements during the Middle Byzantine period," Architecture of Byzantium and Kievan Rus from the 9th to the 12th centuries (Transactions of the State Hermitage Museum LII), Saint Petersburg 2010, 103-104. It should be noted that comparable items used in the 13th century narthex pavement of Pantanassa in Philippias were placed there in second use and their provenance may have

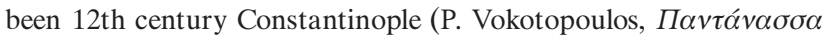
$\Phi \iota \lambda \iota \pi \pi \iota \alpha ́ \delta o \zeta$, Athens 2007, 27-37).

45 P. Androudis, "Le catholicon du monastère byzantine de Saint Démétrios (Chalkéôs) au Mont Athos (actuel Kyriakon de la skite de Saint Démétrios de Vatopédi)," $\triangle X A E K \Theta^{\prime}$ (2008), 195-206, figs 10,

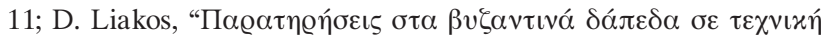

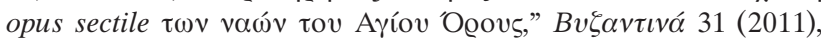

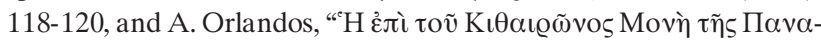

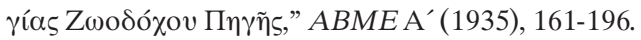


any similarity to the respective Byzantine ones. Besides, even in the hypothetical case that there were technical or stylistic similarities, a Palaeologan date is almost two centuries away from the works proposed for comparison. The misunderstanding is largely due to the lack of a comprehensive study on the Byzantine pavements of Greece, ${ }^{46}$ which has so far led some scholars to regard medieval opus sectile as a uniform phenomenon without geographical and chronological differentiations.

In any case, even in Middle Byzantine pavements and Byzantine iconography more generally, a heart pierced by two arrows is unusual. In Western dogma, where we have the worship of the Sacred Heart of Jesus and the Immaculate Heart of the Virgin, ${ }^{47}$ these can be present even on blazons of monastic orders of the Catholic Church. ${ }^{48}$ In the Orthodox Church, however, the heart alone does not have a religious connotation. Therefore, it is more likely that a heart, especially when placed at the entrance to the church, should be interpreted as the coat of arms of a secular donor. Greek coats of arms of the 17th and 18th centuries $^{49}$ featuring hearts are known, but of course a positive identification cannot be made, since the exact form has long been lost. With considerable reservations, we venture the assumption that the heart-shaped element mentioned falls within the spirit and aesthetics of heraldry during the period of foreign occupation, ${ }^{50}$ perhaps imply-

\footnotetext{
46 This is the subject of the author's doctoral research, currently being carried out at the National Technical University of Athens.

47 The Virgin's heart in particular is portrayed as pierced by one or

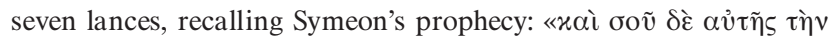

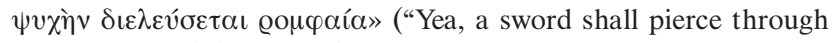
thine soul also") (Luke 2:35).

$48 \mathrm{Cf}$. from the Greek region the 18th century blazon of the Mi-

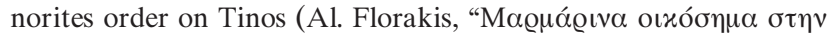

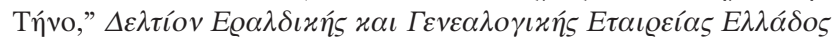
3(1982), 37-73, fig. 32).

${ }^{49}$ Examples in I. Typaldos-Lascaratos - N. Oeconomou - M. Bletas -

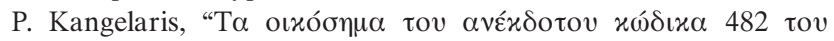
Archivio Antico della Università di Padova," $\Delta \varepsilon \lambda \tau i ́ o v ~ E \varrho \alpha \lambda \delta \iota x \eta ́ \varsigma$

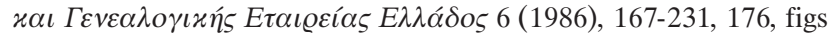

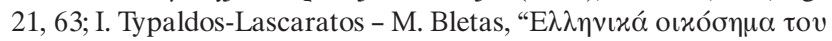

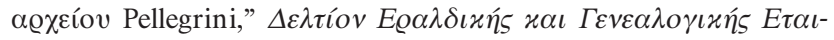

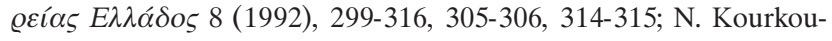

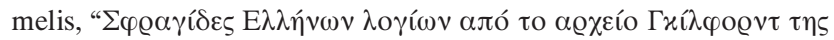

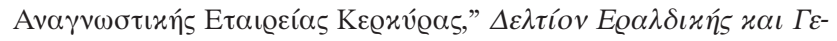

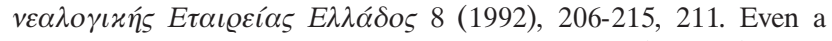
heart- or almond-shaped blazon flanked by lances (of flags) could have been perceived by the visitor who gives us the description as a heart pierced by arrows (cf. the Androutsos coat of arms in Typaldos -Lascaratos - Bletas, op.cit., 299-316, 301-302).

${ }^{50}$ Hearts combined with two intersecting swords, for instance, were depicted on the 18th century flag of Lambros Katsonis [D. Vagia-

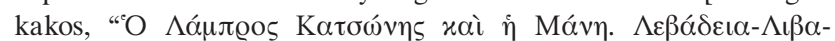

ing a connection to the Hellenic communities in territories under Venetian rule.

Finally, the siren (mermaid) ${ }^{51}$ figure in Greece belongs to the repertoire of Post-Byzantine art par excellence, and not only in maritime areas, as would perhaps have been expected: she appears as an apotropaic figure on stone and timber screens of the 17 th and 18 th centuries, possibly as a result of Western influence, ${ }^{52}$ but she also appears among other creatures in church painting as early as $1619,{ }^{53}$ as well as in other forms of popular art (embroidery, cobbled courtyards, etc.). ${ }^{54}$ Apart from being a mythical sea creature, the mermaid carries a special meaning because she is connected with popular beliefs about Alexander the Great. Of all the legends that tradition attributes to the life of Alexander, the one about his sister (or daughter) who is thrown into the sea and becomes an immortal mermaid after having drunk and then accidentally poured out the Water of Life before Alexander has had the chance to drink it - and who, ever since, has dominated the fate of ships - is perhaps the most widespread and appealing. ${ }^{55}$ Thus, in connection with Alexander, the mermaid acquired nationalist dimensions, particularly as regarded the preeminence of the Greek fleet. ${ }^{56}$ Alexander's personality had become the bearer of the desire for liberation from the time of Byzantine authors, around the period of the Fall of Constantinople; they had connected his victories over the Persians to

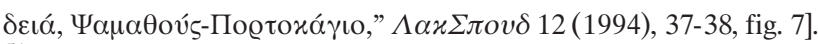
${ }^{51}$ The identification of sirens and mermaids at the time of the descrip-

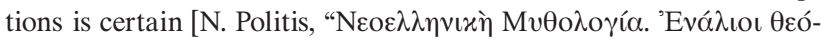
$\tau \eta \tau \varepsilon \varsigma . ~ Г о \varrho \gamma o ́ v \alpha, " ~ П \alpha \varrho v \alpha \sigma \sigma o ̀ \varsigma ~ B, ~ \tau \chi . ~ \Delta^{\prime}$ (April 1878), 259-275, 262264]. Cf. a verse by Epiphanios Demetriades (1760-1827): ( $\eta \theta \alpha ́ \lambda \alpha \sigma-$

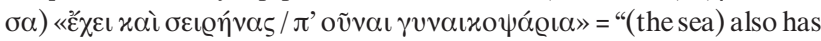

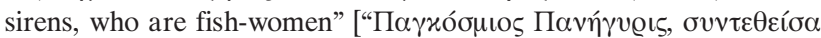

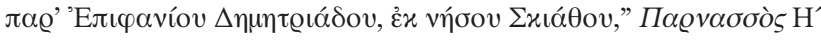
(1884), 408]. In many languages the terms are used interchangeably.

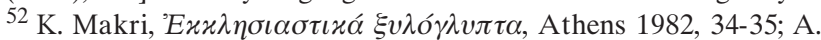

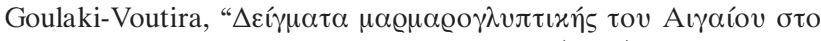

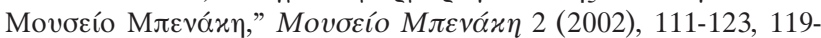
120 , fig. 14 , with additional bibliography.

${ }^{53}$ In the mural paintings in the church of Hagios Nicholaos in Vitsa, Zagori by the painter Michael from Linotopi [A. Tourta, Oı vooi

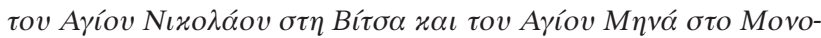

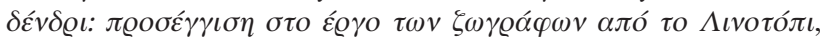

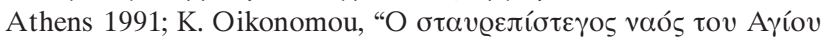

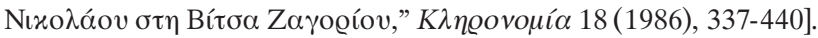

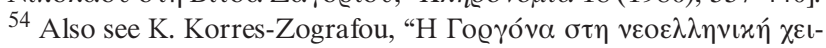

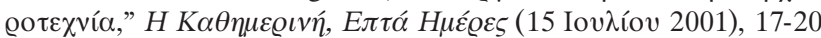

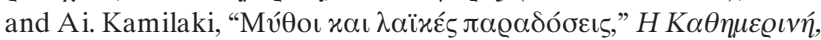

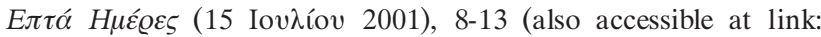
http://wwk.kathimerini.gr/kath/7days/2001/07/15072001.pdf).

55 R. M. Dawkins, "Alexander and the Water of Life," Medium Aevum 6(1937), $186 \mathrm{ff}$

${ }^{56}$ Kamilaki, op.cit. (n. 54), 8-13, 8. 
the Emperor's possibility of victory against the Turks. ${ }^{57}$ From the 17th century onward, such parallels became more frequent, assuming either an inspirational-national character, as after the death of Michael Gennaios, who rebelled against the Turks at the end of the 16 th century, ${ }^{58}$ or the form of a summons to the Tsar and other Orthodox rulers, who are paralleled to Alexander, to liberate the Greeks from the "tyrant." ${ }^{59}$ During the 18th century and the years prior to the Greek Declaration of Independence, this phenomenon became more pronounced, and it continued even after the War of Independence within the framework of irredentist ideas. Indeed, the mermaid's obsession with Alexander's immortality ${ }^{60}$ can be interpreted as a substitute for the immortality of the nation (something expressed in Modern Greek literature) ${ }^{61}$ I believe the presence in Mega Spelaion of the so-called "soldier" with a long lance, positioned as equivalent to the mermaid, represents Alexander himself, holding a spear - the characteristic weapon of antiquity and alludes to the legend. N. Politis notes that until the 19th century, armed ancient warriors found in popular art were called "Macedonians." ${ }^{62}$ Furthermore, the representation of a military figure as purely apotropaic would be rather weak semantically, given that the powerful symbolic significance of such figures derives from their identity, whether saint, hero, or king. The pavement cannot host a saint's form, so it would make sense that the representation refers to a mythical or historical hero. ${ }^{63}$ The mythical narratives surrounding Alexander's life had already been written by PseudoKallisthenes, and various versions were known during the Middle Ages in Byzantium and the West. ${ }^{64}$ Variations in the demotic language were in circulation in the 16th century, and it seems that the narratives were particularly popular during the 17th century, when the Fyllada tou Megalexandrou (1680), a printed pamphlet that became very popular, ${ }^{65}$ was published. Regardless of whether this theory is correct or the figures of the mermaid and the soldier are merely apotropaic, the motifs themselves are characteristic of the Turkish occupation period in Greece.

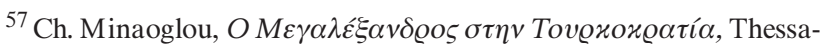

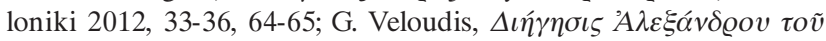

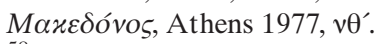

${ }^{58}$ Minaoglou, op.cit. (n. 57), 78; Veloudis, op.cit. (n. 57), $\xi^{\prime}$.

${ }^{59}$ Minaoglou, op.cit. (n. 57), 82-83; Veloudis, op.cit. (n. 57), $v \theta^{\prime}, \xi^{\prime}$.

${ }^{60}$ Her question to the sailors "Does King Alexander live?" anticipated a positive response for her to appease the waves; a negative response provoked her anger.

${ }^{61}$ Veloudis, op.cit. (n. 57), $v \eta^{\prime}-\xi \delta^{\prime}$.

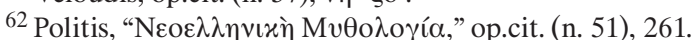

${ }^{63}$ Cf. figures of Samson in medieval pavements or other mythical heroes on textiles, mentioned in the epic poem of Digenes Acritas (see R. Ousterhout, "Architecture, Art and Komnenian Ideology at
}

All the above render the Mega Spelaion pavement indicative of the osmosis of different influences and local traditions in Post-Byzantine art, and perhaps of the reference of a people under foreign rule to symbols of its glorious past. Even the use of opus sectile could be interpreted as such a conscious turn to Byzantium. In fact, it seems plausible that a Late Byzantine opus sectile floor may have pre-existed the present one, as part of an imperial patronage, and influenced the 17th century restorers of the church to create an opus sectile pavement for the new church, repeating some of the previous patterns. This hypothesis would explain why the present floor might mislead us to assign it a Byzantine date, despite the fact that in conception, traits, style, and taste it is Post-Byzantine.

Finally, some remarks regarding the relation of the pavement to the building may also be of relevance. The limitation of the width of the central zone of decoration in the side aisles of the naos, ${ }^{66}$ as opposed to those of the Bema, may attest to an effort to avoid hiding these panels through the placement of stalls, something that would not have occurred during the Byzantine period. Furthermore, there is no construction evidence to indicate that the pavement preceded the building of the church. The octagonal built piers of the actual building show no indication of having tampered with a pre-existing pavement (Fig. 11). Of course, this argument does not entirely preclude such a possibility, since the piers could have taken the exact place of the previous ones. In that case, the destroyed church would have been of the cross-in-square type, like the existing one. However, the actual pavement's design tends to reflect a basilica plan, which perhaps demonstrates the craftsmen's experience with Post-Byzantine spatial arrangements. Byzantine pavements normally display a clearer correspondence to their superstructures, and a hypothetical earlier basilica would have left traces of the positions of additional columns on its pavement.

In conclusion, any attempt to resort to iconographic and technical comparisons to otherwise dissimilar Middle

the Pantokrator Monastery," in N. Necipoğlu (ed.), Byzantine Constantinople: Monuments, Topography and Everyday Life, Leiden - Boston 2001, 146).

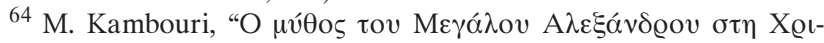

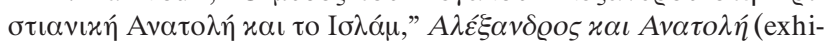

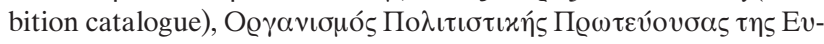

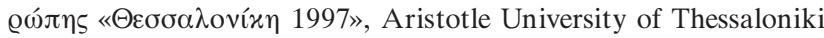

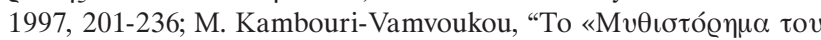

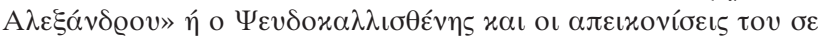

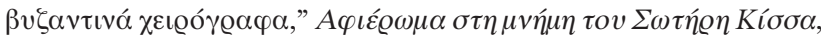
Thessaloniki 2001, 101-133.

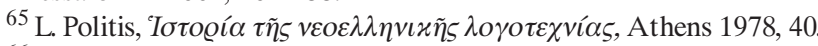

${ }^{66}$ Chotzakoglou, op.cit. (n. 1), 131. 
Byzantine pavements or their contemporaries in Romanesque Italy ${ }^{67}$ to conclude that the subject is Late Byzantine suffers due to the tendency to regard medieval floors as an integral unity independent of their geographic and chronological parameters. ${ }^{68}$ Apart from the stylistic differences mentioned above, a pavement of such uniformity in design and execution would be highly unexpected in the 13th-century Peloponnese, and even more so in the 14th century. A Late Byzantine pavement would normally ${ }^{69}$ include elements absent from Mega Spelaion, including polychromy, a variety of motifs (including combinations of crustae of different sizes, e.g. among intersecting quatrefoils or variations of chessboard patterns), an eclectic spirit in the mix of forms and techniques, and a willingness to present interlacing circles, despite a decline in the accuracy of execution, as we see in the churches of Mystra and the Despotate of Epirus. Therefore, the quality expressed in the accurate execution of a rich but simple design should not be confused with the well-known exquisiteness of Middle Byzantine works ${ }^{70}$ and lead to an early dating, trying to approach that period of acme; on the contrary, it points to a later (Post-Byzantine) one.

Thus, given that the pavement of a church dated to $c a$. 1641 presents a plethora of features befitting the 17th and, perhaps even more so, the 18th century, in order to prove that it is an earlier work, it would take more compelling evidence than general technical similarities, which pertain to a very wide range of this kind of work, ${ }^{71}$ and iconographic comparisons with examples indiscreetly chosen from a broad span of historic periods, styles, and geographic regions, even from beyond the limits of the Empire. ${ }^{72}$ The comparison to Late Byzantine examples in Greece and Asia Minor provides some similarities only in terms of

\footnotetext{
${ }^{67}$ Ibid., 108-120.

${ }^{68}$ For an attempt to approach local trends, see Pinatsi, "Regional Trends and International Exchange," op.cit. (n. 44), 101-117.

${ }^{69}$ The Late Byzantine pavement of the Vlatadon monastery chapel is also not offered for comparison, since that too has been constructed of crustae in second use from an Early Christian pavement or wall

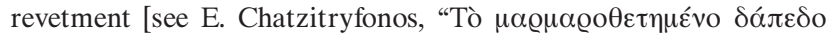

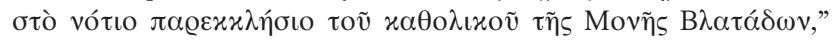
КАпеогоиі́ 14 (1982), 375-406, 381-387].

70 Of course the Mega Spelaion work is nowhere near the superb quality of Middle Byzantine opus sectile, and therefore an even earlier date is excluded.

${ }^{71}$ Chotzakoglou, op.cit. (n. 1), 107-110.

72 Ibid., 108-116, 120, 130. The typological similarity with Monte Cassino, an 11th century pavement, derives rather coincidentally from the similar process of their composition: the integration of a Byzantine technique, on the one hand, in the Monte Cassino basilica,
}

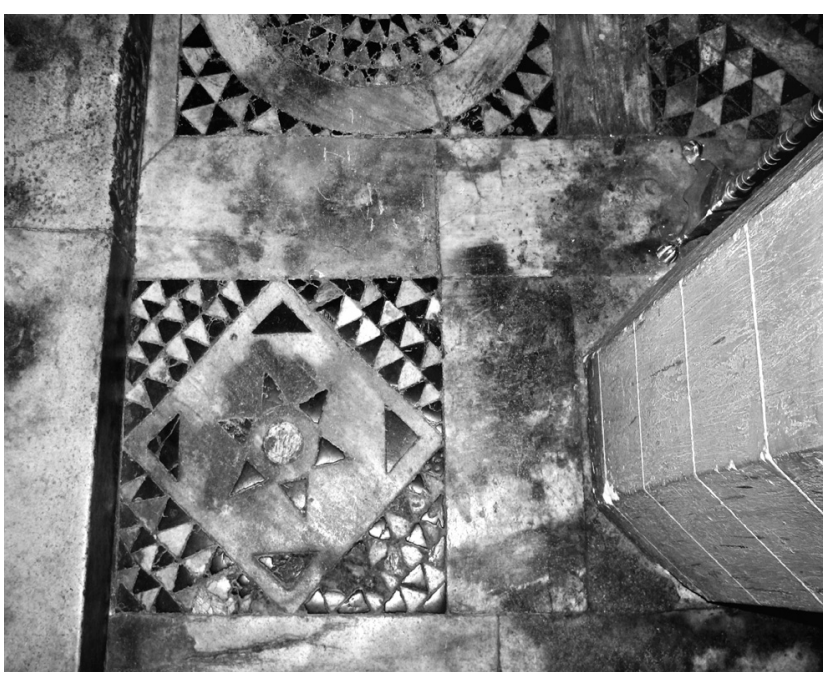

Fig. 11. Mega Spelaion, katholikon. A star incrustation on a marble slab. The relation of the pavement to the pier is noted.

repertoire, whereas references become far more lucid and numerous when the pavement is examined within the artistic context of the Ottoman period. In any case, what must not be overlooked is the fact that the pavement of the Mega Spelaion katholikon is an outstanding work, and its dating to the period of Ottoman rule by no means reduces its value. On the contrary, it reveals a creative tendency in the art of Greece at the time and may possibly attest to a conscious ideology of national aspirations in a monastery that was to become one of the cradles of the struggle for Greek independence. ${ }^{73}$

Architect, MA cpinatsi@yahoo.com

where it is introduced to serve a general layout from the local tradition, which is considered, in point of fact, as the major difference with Byzantine works themselves, and on the other hand, in Mega Spelaion, to serve a new tendency in design, has led to analogous results in terms of their general plan.

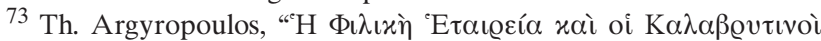

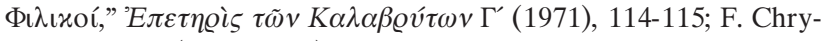

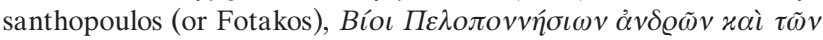

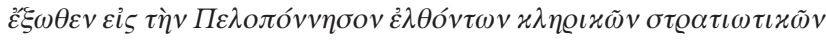

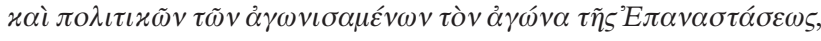

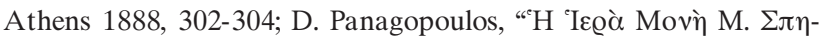

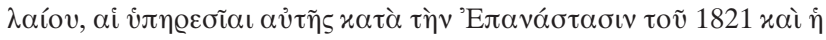

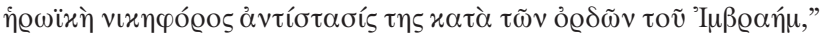

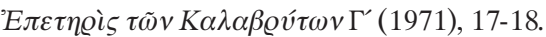

\section{Illustration Credits}

Figs 1-11: Ch. Pinatsi. 


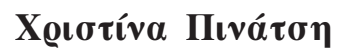

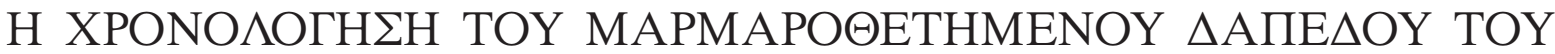

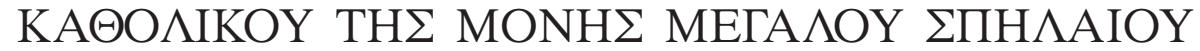

$\mathrm{T}$

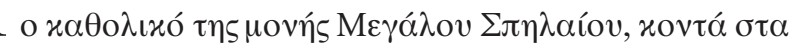

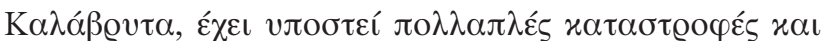

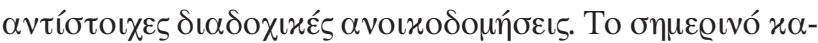

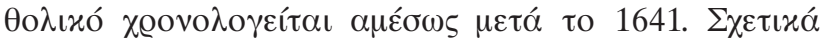

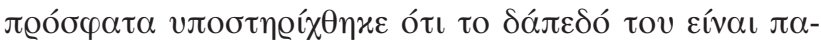

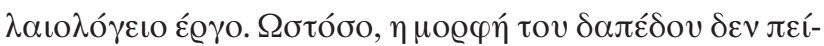

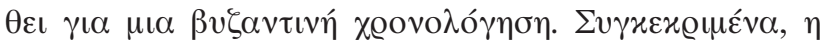

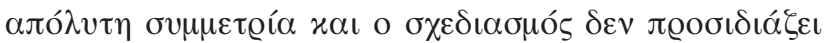

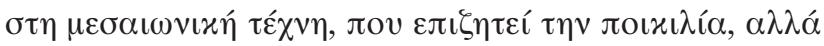

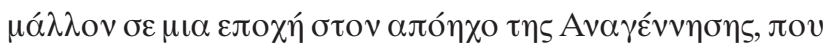

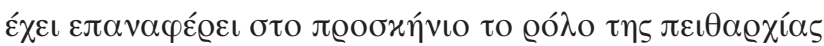

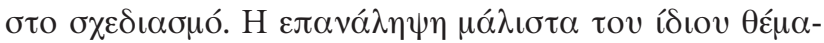

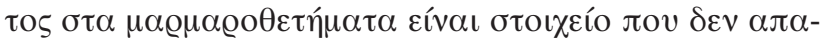

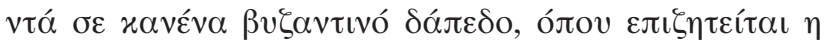

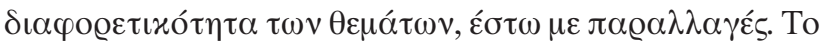

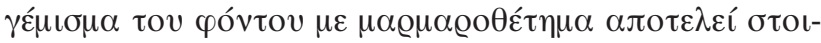

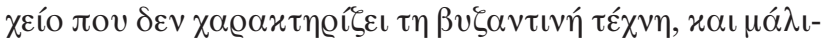

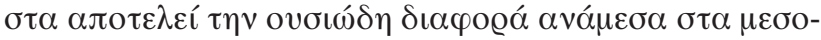

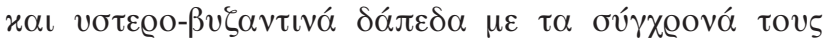
cosmati $x \alpha \iota \tau \alpha \pi \alpha \lambda \alpha \iota \chi \varrho\llcorner\sigma \tau \iota \alpha \iota x \alpha ́$.

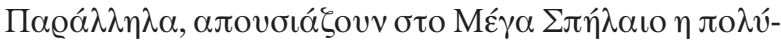

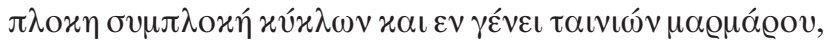

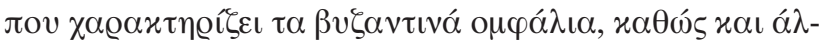

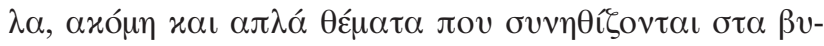

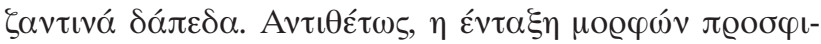

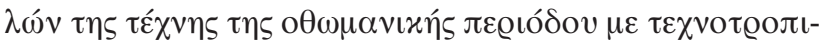

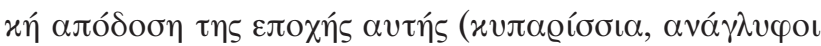

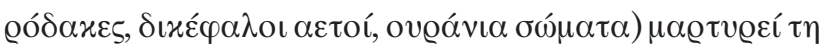

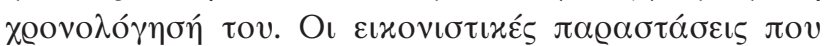

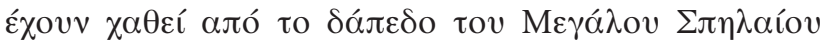

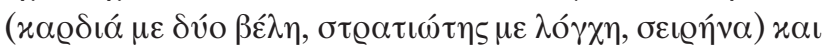

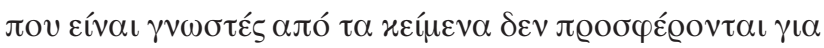

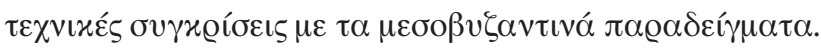

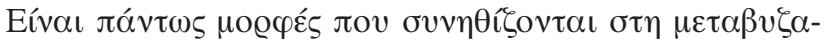

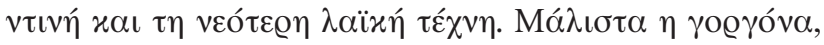

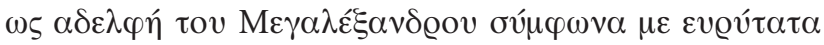

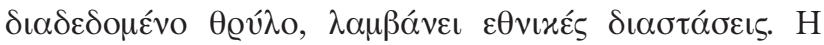

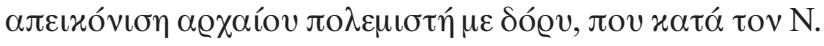

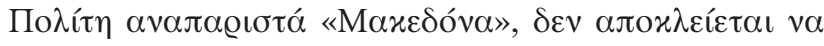

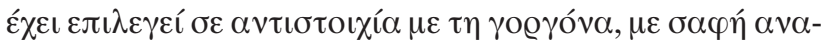

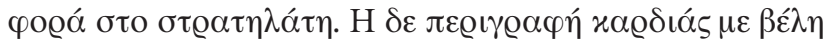

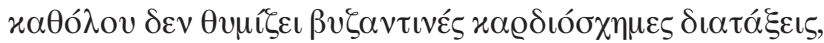

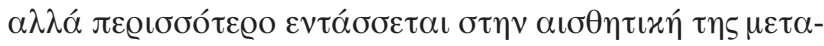

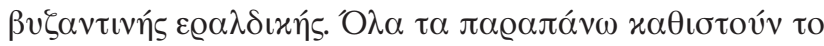

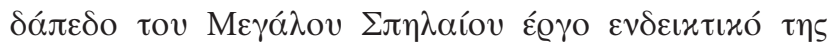

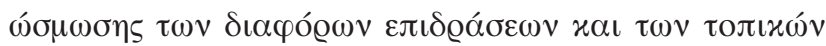

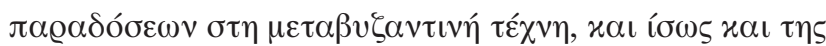

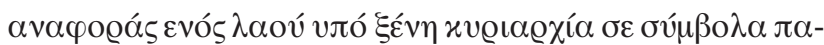

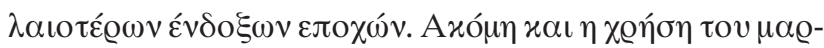

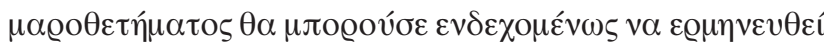

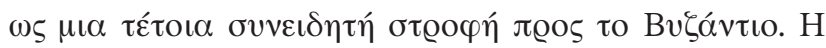

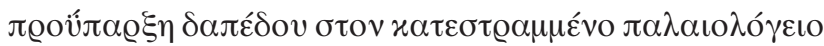

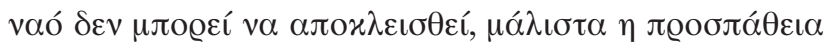

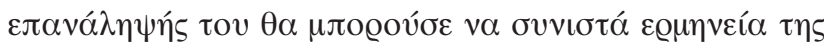

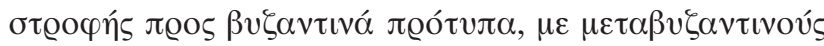

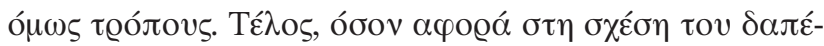

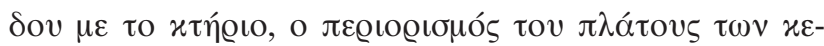

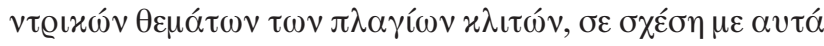

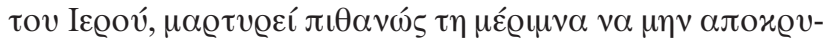

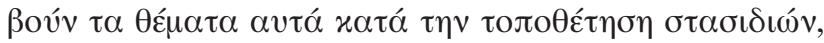

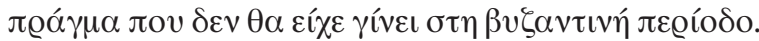

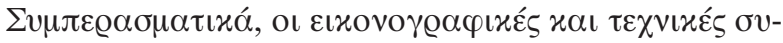

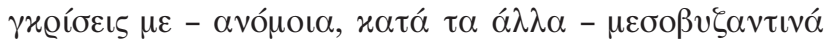

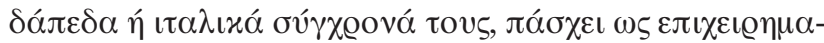

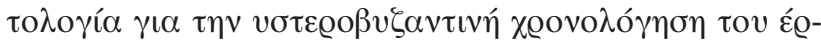

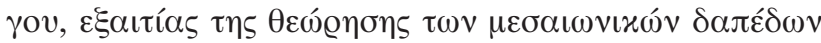

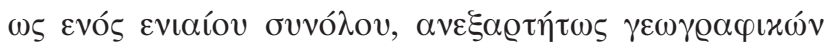

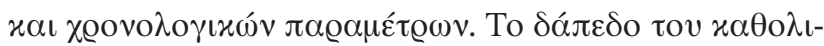

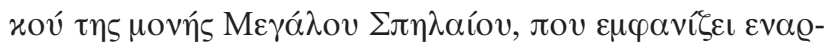

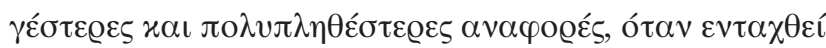

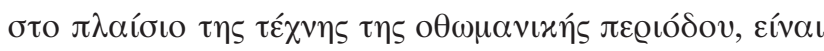

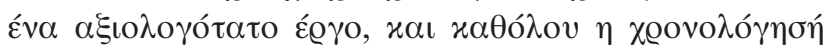

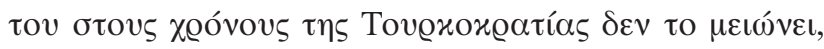

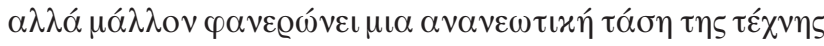

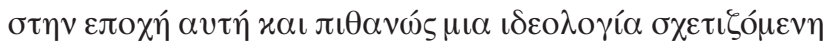

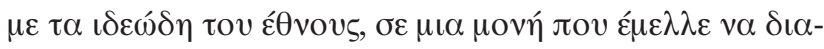

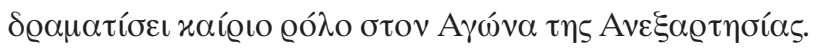

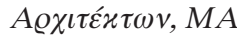
cpinatsi@yahoo.com 